\title{
Depression and Memory Decline in the Elderly
}

\author{
Andréa Guedes Machado \\ Paola Andressa Lima Dornelles \\ Departamento de Psicologia, Universidade Federal de Ciências da Saúde de Porto Alegre, \\ Porto Alegre, RS, Brazil \\ Fabiana Michelsen de Andrade \\ Instituto de Ciências da Saúde, Universidade Feevale, Novo Hamburgo, RS, Brazil \\ Marilu Fiegenbaum \\ Departamento de Ciências Básicas da Saúde, Universidade Federal de Ciências da Saúde \\ de Porto Alegre, Porto Alegre, RS, Brazil \\ Analuiza Camozzato de Pádua \\ Departamento de Clínica Médica, Universidade Federal de Ciências da Saúde \\ de Porto Alegre, Porto Alegre, RS, Brazil \\ Alcyr Alves de Oliveira ${ }^{1}$ \\ Departamento de Psicologia, Universidade Federal de Ciências da Saúde de Porto Alegre, \\ Porto Alegre, RS, Brazil
}

\begin{abstract}
Objective: To analyze the memory performance of participants aged 60 years and older with and without depressive symptoms. Methods: 199 participants were assessed using the Beck Depression Inventory (BDI) with a cut-off point of 20 for depression. Of these, 22 met the criteria for depression group; the remaining participants were allocated to the non-depression group. The Rey Auditory-Verbal Learning Test (RAVLT) was used to assess verbal learning, figures I and II of the Visual Reproduction subtest of the Wechsler Memory Scale Revised (WMS-R) was used to evaluate immediate and delayed visual memory, and the Logical Memory subtests I and II of WMS-R were used to test verbal memory. Results: The average scores for verbal learning in the depression group were significantly lower than those in the non-depression group $(p=.001)$. There were no group differences on visual and logical memory I and II scales. Conclusion: Depressive symptoms affect information retention and verbal learning in the elderly. However, they had no effect on visual and logical memory processing in this sample. The results suggest that, in addition to age-related cognitive decline, depression impairs memory performance considerably.
\end{abstract}

Keywords: Memory, aging, depressive disorder, Geriatric Psychiatry.

\section{Depressão e Declínio de Memória em Idosos}

\section{Resumo}

Objetivo: analisar o desempenho de memória de participantes com 60 anos ou mais de idade, apresentando ou não sintomas de depressão. Métodos: 199 participantes foram examinados através do Inventário de

\footnotetext{
Mailing address: Universidade Federal de Ciências da Saúde de Porto Alegre - UFCSPA, Departamento de Psicologia, Rua Sarmento Leite, 245, sala 207, Porto Alegre, RS, Brazil. Phone: (51) 33038826. E-mail: alcyr@ufcspa.edu.br
} 
Depressão de Beck (BDI) com ponto de corte em 20 pontos para depressão. 22 participantes atingiram o critério para inclusão no grupo de depressão e o restante foi alocado no grupo sem depressão. Os testes utilizados foram: Rey Auditory-Verbal Learning Test (RAVLT) para avaliar aprendizagem verbal, teste de reprodução de figuras I e II da Escala Wechsler Revisada (WMS-R) para memória visual imediata e duradoura e teste de memória lógica I e II da WMS-R para memória verbal. Resultados: os escores médios para aprendizagem verbal no grupo com depressão foram significativamente mais baixos do que no grupo sem depressão $(p=0,001)$. Não ocorreram diferenças significativas entre os grupos nas escalas para memória visual ou lógica I e II. Conclusões: sintomas de depressão afetam a retenção de informação e a aprendizagem verbal em idosos. Entretanto, não parecem afetar o processamento das memórias visual e lógica. Os resultados sugerem que, além do declínio cognitivo devido ao envelhecimento, a presença de depressão afeta e empobrece o desempenho de memória.

Palavras-chave: Memória, envelhecimento, desordem depressiva, Psiquiatria Geriátrica.

\section{La Depresión y el Deterioro de la Memoria en Personas Mayores}

\section{Resumen}

Objectivo: Analizar el rendimiento de la memoria de participantes con más de 60 años con síntomas de depresión. Métodos: 199 participantes fueron examinados a través del Inventario de Depresión de Beck (BDI), tomando en consideracion acima de 20 puntos para la depresión. 22 participantes alcanzaron el criterio de inclusión en el grupo de depresión y lo restante fue colocado en el grupo sin depresión. Las pruebas utilizadas fueron: Rey Auditory-Verbal Learning Test para evaluar el aprendizaje verbal; Prueba de Reproducción de Figuras I y II de Wechsler Memory Scale (WMS-R) para memoria inmediata y duradera, memoria visual y lógica de ensayo I y II de la WMS-R para memoria verbal. Resultados: La aprendizaje verbal en el grupo con depresión fue abajo que en el grupo sin depresión $(p=.001)$. No hubo diferencias significativas entre los grupos en las escalas para memoria I y II visual y lógica. Conclusiones: La depresión afecta la retención de información y aprendizaje verbal en los ancianos pero no parece afectar el procesamiento de los recuerdos visuales y lógicos. Los resultados sugieren que, además de deterioro cognitivo debido al envejecimiento, afecta a la presencia de depresión y el rendimiento de la memoria se vuelve pobre.

Palabras clave: Memoria, envejecimiento, trastorno depressivo, Psiquiatría Geriátrica.

Interest on aging research is rising owing to increasing longevity in almost all countries (Oliveira, 2007a). Data from the World Health Organization (WHO, 2012) suggest that improved access to basic health services have been fundamental to enlarging the elderly population. Consequently, the number of studies on this population has also grown considerably, especially on the unhealthy aging processes. Cognitive, physiological, and neurological changes are common during aging (Braver \& Barch, 2002). Studies of the relationship between aging and mental and neurological conditions pose important questions about normal age-related decline (Braver \& Barch, 2002).

During the aging process, memory impairment might be unobtrusive and discrete, especially for operational memory, retention and learning capabilities (Braver \& Barch, 2002; Garcia et al., 2006; Oliveira, 2007b). In the context of lower education levels and more advanced age, impoverished cognition declares itself more readily (Fichman et al., 2010; Magalhães \& Hamdan, 2010). In verbal learning tests, such as lists of words, the elderly tend to remember more of the first and last words, and improve their performance with repetition (Brehmer, 
Westerberg, \& Bäckman, 2012; Spinnler, Sala, Bandera, \& Baddeley, 1988). Elderly subjects perform better on tests of incidental memory than on those requiring effortful operations, such as rehearsal and elaborative mnemonic activities (Hasher \& Zacks, 1979; McCabe, Roediger, \& Karpicke, 2011; Turner, Furey, Drevets, Zarate, $\&$ Nugent, 2012).

Memory is deeply influenced by emotional states, motivation, and attention (Jaeger \& Parente, 2007). Recalling a memory is an act influenced by mood states (Izquierdo, 2002) and is sensitive to pathological conditions, such as depression (Izquierdo, 2002; Pelosi, Slade, Blumhardt, \& Sharma, 2000). Depressed people have an increased tendency toward negative bias in explicit memory recall (Izquierdo, 2002; Jaeger \& Parente, 2007; Nitschke, Heller, Etienne, \& Miller, 2004).

Elderly patients with depression usually do not present differently to subjects without depression on tests of logical verbal memory when information is presented in a narrative form (Lamar, Charlton, Zhang, \& Kumar, 2012). However, poorer working memory performances (Lamar et al., 2012; Nitschke et al., 2004; Pelosi et al., 2000) and impairment of immediate (Nebes et al., 2000), delayed logical memory (Elderkin-Thompson, Mintz, Haroon, Lavretsky, \& Kumar, 2007), and immediate visual memory (Nebes et al., 2000) have also been observed in elderly individuals with depression.

Depressed patients differ from healthy subjects on verbal learning tasks, in which information is presented as a list of words (Lamar et al., 2012) and information recall is poorer in verbal learning (Fossati, Coyette, Ergis, \& Allilaire, 2002; Lamar et al., 2012; Nebes et al., 2000), reading, verbal, and non-verbal memory (Elderkin-Thompson et al., 2003; Rozenthal, Laks, \& Engelhardt, 2004).

Therefore, verbal learning, visual, and verbal memory in the depressed elderly might be more impaired than in non-depressed elderly people. The aim of this study was to investigate the performance of verbal learning and the recall of visual and verbal material in elderly subjects with and without depression.

\section{Methods}

This is a cross-sectional study with a predominantly community-based sample. Participants were recruited through announcements at centers for elderly activities, community centers, parks, and invitations to inpatients from the Hospital Materno Infantil Presidente Vargas in the city of Porto Alegre. The inclusion criteria were age $\geq 60$ years, literacy, and ability to understand and sign the Informed Consent Form. The exclusion criterion was the presence of self-reported neurologic disease. 199 participants were assessed and 22 met the criteria for depression.

The study was approved by the Universidade Federal de Ciências da Saúde de Porto Alegre (CEP/UFCSPA number 250,310) and the Hospital Materno Infantil Presidente Vargas (CEP/HMIPV number 279,993) Ethics Committees.

\section{Materials}

The instruments used for this study were:

Beck Depression Inventory (BDI; Beck, Ward, Mendelson, Mock, \& Erbaugh, 1961; Gorenstein \& Andrade, 1996). The BDI is a self-report inventory with 21 items related to depression symptoms with intensity ranging from 0 to 3 (a rating of 0 indicates the absence of a symptom whereas a rating of 3 indicates a severe symptom) and total score ranging from 0 to 63 . Higher scores (in total and in each item) indicate more severe depressive symptoms (Cunha, 2001). In this study, scores of 20 or higher were set as the cut-off point for depression, following the recommendation of Gorenstein and Andrade (1998), Kendall, Hollon, Beck, Hammen, and Ingram (1987), and Wechsler (1987).

Rey Auditory-Verbal Learning Test (RAVLT; Diniz \& Cruz, 2000). The RAVLT is employed to detect deficits in verbal memory (Cotta et al., 2012; Malloy-Diniz, Lasmar, Gazinelli, Fuentes, $\&$ Salgado, 2007). A 15 -word list is read at a rate of one word per second, and the patient is asked to say, in any order, as many of the words he can remember. The procedure is repeated four times and the total number of words recalled in 
all attempts is tallied for the final score. This test assesses short-term memory, verbal learning, retention capacity for new information, and free recall ability.

Visual Reproduction of Figures I and II of the Wechsler Memory Scale Revised (WMS-R, VR I and II; Wechsler, 1987). Four geometric designs printed on individual cards are presented to patients. Immediately thereafter, they are asked to draw what they remember of each design. This test is used to evaluate immediate visual memory (VR I). Delayed visual memory (VR II) is measured after a short time, through the free recall of figures, without allowing participants to see the design again.

Logical Memory I and II tests from the Wechsler Memory Scale Revised (WMS-R, LOG I and II; Wechsler, 1987). Delayed Verbal Memory or Logical Memory II (LOG II) was assessed using free recall of stories without repetition. This test measures the ability to process information requiring more sophisticated storage, understanding, and categorization. Lower level responses may indicate organization deficits. The logical memory immediate or logical memory I (LOG I) evaluates, through free recall, the ability to retain contents from two stories presented orally.

\section{Procedure}

Participants were informed about the purpose of the study and signed the consent form. 199 participants participated in the study and were tested in the following order of test application: Logical Memory of the Wechsler Memory Scale Revised I (WMS-R) I, Visual Reproduction of Figures of (WMS-R) I, Beck Depression Inventory (BDI), Logical Memory Scale Wechsler Memory Scale-Revised (WMS-R) II, Visual Reproduction of Figures of (WMS-R) II and Test of Learning AuditoryVerbal Rey (RAVLT).

\section{Statistical Analysis}

The total scores of each memory test and the age and education levels of participants in the two groups were compared using the Student's $t$ test. The relationship between gender and depression was assessed using the Chi-square test. The variables that demonstrated significant association with depression in the univariate model were entered in a binary logistic regression model for the outcome depression. Correlation of BDI total score with age, education, Logical Memory of the Wechsler Memory Scale Revised I (WMS-R) I, Visual Reproduction of Figures of (WMS-R) I, Logical Memory Scale Wechsler Memory Scale-Revised (WMS-R) II, Visual Reproduction of Figures of (WMS-R) II and Test of Learning Auditory-Verbal Rey (RAVLT) were evaluated using the Pearson Correlation Test. The variables that correlated significantly with BDI score were entered into a linear regression model. All data were analyzed using the SPSS version 17.0 with $p<.05$.

\section{Results}

Mean $(S D)$ age $=67.26(5,98)$ and mean $(S D)$ years of education $=9.68(4.87)$. The sample consisted of 160 female $(80.4 \%)$ and 39 male $(19.6 \%)$ participants. Mean $(S D)$ of tests of logical memory (immediate Log I) and delayed $($ LOG II $)=-0.09(1.0)$ and $-0.06(1.02)$, respectively. On tests of immediate visual memory (VR I), delayed visual memory (VR II), RAVLT, and BDI, mean $(S D)=-0.28(1,34),-0.36(1,25)$, $-0.36(1,32)$, and $8.80(7,89)$, respectively. The total sample scores on BDI ranged from 0 to 39 with mean $(S D)$ of 8.80 (7.89). Adopting the cut-off point of 20 on BDI, from the initial 199 participants that took part in the study, 22 participants met inclusion criteria for depression, $11 \%$ of the total sample examined. This result is consistent with the incidence of depression in the Brazilian, approximately 13\% (Pinho, Custódio, \& Makdisse, 2009). Table 1 presents the comparison of demographic data and scores on memory tests between groups with and without depression. The group with depression had significantly lower education, lower age, and lower RAVLT scores than subjects without depression. 
Table 1

Comparison of Demographics and Performance on Memory Test between EIderly Subjects with and Without Depression

\begin{tabular}{cccc}
\hline Variable & $\begin{array}{c}\text { Group with Depression } \\
(N=22)\end{array}$ & $\begin{array}{c}\text { Group without Depression } \\
(N=177)\end{array}$ & $p$-value \\
\hline Age*(mean $\pm S D)$ & $65.32 \pm 4.087$ & $67.50 \pm 6.139$ & .033 \\
$\begin{array}{c}\text { Schooling* (years of study) } \\
(\text { mean } \pm S D)\end{array}$ & $7.33 \pm 4.144$ & $9.92 \pm 4.889$ & .022 \\
Sex $(N)(\%)$ female** & $20(12.5 \%)$ & $140(87.5 \%)$ & .259 \\
LOG I* (mean $\pm S D)$ & $-0.3808 \pm 1.34892$ & $-0.0530 \pm 1.00294$ & .281 \\
LOG II* $(\operatorname{mean} \pm S D)$ & $-0.1945 \pm 1.14403$ & $-0.0391 \pm 1.00327$ & .548 \\
VR I* $(\operatorname{mean} \pm S D)$ & $-0.22 \pm 1.368$ & $-0.29 \pm 1.344$ & .824 \\
VR II* $(\operatorname{mean} \pm S D)$ & $-0.21 \pm 1.304$ & $-0.37 \pm 1.243$ & .588 \\
RAVLT $*(\operatorname{mean} \pm S D)$ & $-1.3241 \pm 1.32608$ & $-0.2389 \pm 1.26891$ & .001 \\
\hline
\end{tabular}

Note. * Student $t$-test; ** Chi-Square; *** Age, Schooling, RAVLT = significant difference. LOG I: Immediate Logical Memory, LOG II: Delayed Logical Memory, VR I: Immediate Visual Memory, VR II: Delayed Visual Memory, RAVLT: Rey Auditory Verbal Learning Test.

Table 2

Logistic Regression Analysis for the Outcome of Depression

\begin{tabular}{cccc}
\hline Variables & B & OR $(95 \% \mathrm{CI})$ & $P$ \\
\hline Age & -0.110 & $0.896(0.806-0.996)$ & .042 \\
Schooling & -0.092 & $0.912(0.806-1.032)$ & .145 \\
RAVLT & -0.535 & $0.586(0.366-0.937)$ & .026 \\
\hline
\end{tabular}

Note. Variables: Age, Years of study, RAVLT.

Table 2 shows the binary logistic regression for the outcome depression. Age, education, and RAVLT were independent variables in this model. Scores of younger individuals and those with lower performance on RAVLT were significantly and independently associated with depression in this analysis.

BDI total score showed a significant weak negative correlation with schooling $(r=-0.27$, $p=.022$ ) (Pearson correlation test) and with RAVLT total score $(r=-0.29, p=.001$; Pearson correlation test). Age was significantly lower in the group of subjects with depression ( $p=$ .033). No significant correlations of BDI total score with Immediate Logical Memory, Delayed Logical Memory, Immediate Visual Memory, and Delayed Visual Memory were observed. In the logistic regression model, the performance on
RAVLT remained significantly associated with depression when adjusted for age and education $(\mathrm{OR}=0.586, \mathrm{CI}=0.366-0.937, p=.026)$.

\section{Discussion}

The objective of this study was to evaluate the effect of depressive symptoms on memory in the elderly and in mature adulthood. The results showed that patients with major depression (BDI scores $\geq 20$ points) had impoverished performance on recent memory, verbal learning, and capacity to retention new information and spontaneous recall. Visual and logical memory performance differences between depressed and non-depressed participants were not verified. When the outcome was evaluated as categorical (presence/absence of depression) younger 
age and poorer performance on RAVLT were independent and significantly associated with depression.

These results support the hypothesis that elderly patients with depressive symptoms present with global memory impairment; that is, with poorer performance on tests of verbal learning, immediate, and delayed visual and logical verbal memory. However, our results confirmed poorer scores only on RAVLT test in individuals with depression. The results therefore indicate a poor performance on verbal learning, since the RALVT measures verbal learning and ability to store new information. In both multiple statistical models (binary logistic regression and linear regression), the RAVLT score remained significantly and independently associated with depression or depressive symptoms. This association was adjusted for age and education, and was also associated with depression, thus potentially representing confounding variables.

Poorer performance in elderly patients with depression on specific tests of verbal and visual memory were not observed, despite the literature pointing to lower performance on verbal and non-verbal evocation in these subjects (Elderkin-Thompson et al., 2003; Nebes et al., 2000). Since the tests were applied according to the model of Wechsler, 1987), we can say that we measured memory using more structured tests. Memory, however, cannot be understood as a separate learning structure. The RAVLT is a more comprehensive memory test, which also evaluates recent verbal memory, as all other tests also assess, as well as the ability to retain new information, besides the evaluation of verbal learning. Therefore, it is worth questioning the reason for these differences in scores between the RAVLT and the LOG I, as both measure immediate verbal memory. LOG $\mathrm{I}$ is presented in narrative form; the RAVLT as a list of words. In this study, individuals with symptoms of depression, when compared with subjects without these symptoms, performed worse on the list of words, but not on narrative recall. One study has already demonstrated that individuals with depression, compared with subjects without depression, demonstrate greater verbal memory deficits when the verbal stimuli were presented in the form of word lists; the same result was not observed when verbal stimuli were presented in narrative form, suggesting that this difference might be due to the involvement of different neural areas for the two types of presentation of verbal stimuli (Lamar et al., 2012).

Depression involves anhedonia as one of its main symptoms; that is, lack of motivation to execute proposed tasks (Garcia et al., 2006; Mello \& Teixeira, 2011). Lack of attention is also a predominant aspect of depression. Some studies have shown that elderly patients with a diagnosis of depression may present with more divided attention than do elderly patients with depressive symptoms (Ávila \& Bottino, 2006). It is thus reasonable to suggest that the anhedonia and lack of attention can exacerbate performance deficits on tests presented in the form of word lists. As the objective of this study was not to identify the reasons for score differences on the two tests of verbal memory, the execution of further studies including tests to measure the motivation and attention of the participants before the memory tests, is proposed.

One possible limitation of the present study was that the depression diagnosis was not supported by clinical diagnosis. Even so, the cut-off point of 20 on BDI has excellent diagnostic accuracy in identifying major depression (Gorenstein \& Andrade, 1998; Kendall et al., 1987). Additionally, the presence of clinical comorbidities that could affect cognition, as well as psychotic symptoms which might impact the results, was not assessed.

In summary, the purpose of this study was to evaluate different types of memory and to compare scores among older adults with and without symptoms of depression. The results showed impairment of verbal learning skills in depressive subjects. Learning and memory are complex, requiring, among other cognitive skills, attention and motivation. The results suggest that depressed aging individuals are already compromised on these two functions, leading to a decline in recent memory, verbal learning, the ability to retain new information, and spontaneous recall when tested with repeated presenta- 
tions of a word list. Depression had no effect on the performance of tests in which the memory accessed involved verbal narratives or visual stimuli. As other studies have reported contradictory findings (Elderkin-Thompson et al., 2003; Lamar et al., 2012; Nebes et al., 2000), this issue should be further investigated in future studies.

\section{Conclusion}

The main objective of the study was to investigate verbal learning and visual and verbal memory recall in elderly people and to observe the effects of depression in this population.

It has been previously reported that depressive symptoms affect information retention and verbal learning. In elderly people, this affect appears stronger, although this might not necessarily be related only to aging. In this study, it has been shown that depression causes a more marked memory decline than observed in aging people. However, it does not seem to affect visual and logical memory processing. The results suggest that depression might exacerbate the memory deficits inherent to normal age-related cognitive decline.

\section{Referências}

Ávila, R., \& Bottino, C. M. de C. (2006). Cognitive changes update among elderly with depressive syndrome. Revista Brasileira de Psiquiatria, 28(4), 316-320. doi:http://doi.org/10.1590/ S1516-44462006005000010

Beck, A. T., Ward, C. H., Mendelson, M., Mock, J., \& Erbaugh, J. (1961). An inventory for measuring depression. Archives of General Psychiatry, 4, 561-571.

Braver, T. S., \& Barch, D. M. (2002). A theory of cognitive control, aging cognition, and neuromodulation. Neuroscience and Biobehavioral Reviews, 26(7), 809-817.

Brehmer, Y., Westerberg, H., \& Bäckman, L. (2012). Working-memory training in younger and older adults: Training gains, transfer, and maintenance. Frontiers in Human Neuroscience, 6. doi:http://doi.org/10.3389/fnhum.2012.00063

Cotta, M. F., Malloy-Diniz, L. F., Nicolato, R., Moares, E. N. de, Rocha, F. L., \& Paula, J. J. de.
(2012). O teste de aprendizagem auditivo-verbal de Rey (RAVLT) no diagnóstico diferencial do envelhecimento cognitivo normal e patológico. Contextos Clínicos, 5(1), 10-25. doi:http://doi. org/10.4013/ctc.2012.51.02

Cunha, J. A. (2001). Manual da versão em português das Escalas Beck. São Paulo, SP: Casa do Psicólogo.

Diniz, L. F. M., \& Cruz, M. de F. da. (2000). O teste de aprendizagem auditivo-verbal de Rey: Normas para uma população brasileira. Revista Brasileira de Neurologia, 79-83.

Elderkin-Thompson, V., Kumar, A., Bilker, W. B., Dunkin, J. J., Mintz, J., Moberg, P. J., ...Gur, R. E. (2003). Neuropsychological deficits among patients with late-onset minor and major depression. Archives of Clinical Neuropsychology: The Official Journal of the National Academy of Neuropsychologists, 18(5), 529-549.

Elderkin-Thompson, V., Mintz, J., Haroon, E., Lavretsky, H., \& Kumar, A. (2007). Executive dysfunction and memory in older patients with major and minor depression. Archives of Clinical Neuropsychology: The Official Journal of the National Academy of Neuropsychologists, 22(2), 261-270.

Fichman, H. C., Dias, L. B. T., Fernandes, C. S., Lourenço, R., Caramelli, P., \& Nitrini, R. (2010). Normative data and construct validity of the Rey Auditory Verbal Learning Test in a Brazilian elderly population. Psychology \& Neuroscience, 3(1), 79-84.

Fossati, P., Coyette, F., Ergis, A.-M., \& Allilaire, J.-F. (2002). Influence of age and executive functioning on verbal memory of inpatients with depression. Journal of Affective Disorders, 68(2-3), 261-271.

Garcia, A., Passos, A., Campo, A. T., Pinheiro, E., Barroso, F., Coutinho, G., ...Sholl-Franco, A. (2006). A depressão e o processo de envelhecimento. Ciências \& Cognição, 7, 111-121.

Gorenstein, C., \& Andrade, L. (1996). Validation of a Portuguese version of the Beck Depression Inventory and the State-Trait Anxiety Inventory in Brazilian subjects. Brazilian Journal of Medical and Biological Research, 29(4), 453-457.

Gorenstein, C., \& Andrade, L. (1998). Inventário de Beck: Propriedades psicométricas da versão em Português. Revista de Psiquiatria Clínica, 25, 245-250. 
Hasher, L., \& Zacks, R. T. (1979). Automatic and effortful processes in memory. Journal of Experimental Psychology: General, 108(3), 356-388. doi:http://doi.org/10.1037/0096-3445.108.3.356

Izquierdo, I. (2002). Memória. Porto Alegre, RS: Artmed.

Jaeger, A., \& Parente, M. A. M. P. P. (2007). Memória, emoções e seus correlatos eletrofisiológicos. In A. Oliveira (Ed.), Memória: Cognição e Comportamento (pp. 185-207). São Paulo, SP: Casa do Psicólogo.

Kendall, P. C., Hollon, S. D., Beck, A. T., Hammen, C. L., \& Ingram, R. E. (1987). Issues and recommendations regarding use of the Beck Depression Inventory. Cognitive Therapy and Research, 11(3), 289-299. doi:http:/doi. org/10.1007/BF01186280

Lamar, M., Charlton, R., Zhang, A., \& Kumar, A. (2012). Differential associations between types of verbal memory and prefrontal brain structure in healthy aging and late life depression. Neuropsychologia, 50(8), 1823-1829. doi:http://doi. org/10.1016/j.neuropsychologia.2012.04.007

Magalhães, S. S., \& Hamdan, A. C. (2010). The Rey Auditory Verbal Learning Test: Normative data for the Brazilian population and analysis of the influence of demographic variables. Psychology \& Neuroscience, 3(1), 85-91. doi:http://doi. org/10.3922/j.psns.2010.1.011

Malloy-Diniz, L. F., Lasmar, V. A. P., Gazinelli, L. de S. R., Fuentes, D., \& Salgado, J. V. (2007). The Rey Auditory-Verbal Learning Test: Applicability for the Brazilian elderly population. Revista Brasileira De Psiquiatria, 29(4), 324-329.

McCabe, D. P., Roediger, H. L., \& Karpicke, J. D. (2011). Automatic processing influences free recall: Converging evidence from the process dissociation procedure and remember-know judgments. Memory \& Cognition, 39(3), 389-402. doi:http://doi.org/10.3758/s13421-010-0040-5

Mello, E., \& Teixeira, M. B. (2011). Depressão em idosos. Revista Saúde, 5(1), 42-53.

Nebes, R. D., Butters, M. A., Mulsant, B. H., Pollock, B. G., Zmuda, M. D., Houck, P. R., \& Reynolds, C. F. (2000). Decreased working memory and processing speed mediate cognitive impairment in geriatric depression. Psychological Medicine, 30(3), 679-691.

Nitschke, J. B., Heller, W., Etienne, M. A., \& Miller, G. A. (2004). Prefrontal cortex activity differentiates processes affecting memory in depression. Biological Psychology, 67(12), 125-143. doi:http://doi.org/10.1016/j. biopsycho.2004.03.004

Oliveira, A. (2007a). Memória: O que podemos aprender e o que podemos ensinar. In A. Oliveira (Ed.), Memória: Cognição e Comportamento (pp. 13-15). São Paulo, SP: Casa do Psicólogo.

Oliveira, A. (2007b). Uma breve história da pesquisa da memória. In A. Oliveira (Ed.), Memória: Cognição e Comportamento (pp. 17-36). São Paulo, SP: Casa do Psicólogo.

Pelosi, L., Slade, T., Blumhardt, L. D., \& Sharma, V. K. (2000). Working memory dysfunction in major depression: An event-related potential study. Clinical Neurophysiology: Official Journal of the International Federation of Clinical Neurophysiology, 111(9), 1531-1543.

Pinho, M. X., Custódio, O., \& Makdisse, M. (2009). Incidência de depressão e fatores associados em idosos residentes na comunidade: Revisão de literatura. Revista Brasileira de Geriatria e Gerontologia, 12(1), 123-140.

Rozenthal, M., Laks, J., \& Engelhardt, E. (2004). Neuropsychological aspects of depression. Revista de Psiquiatria do Rio Grande do Sul, 26(2), 204-212. doi:http://doi.org/doi.org/10.1590/ S0101-81082004000200010

Spinnler, H., Sala, S. D., Bandera, R., \& Baddeley, A. (1988). Dementia, ageing, and the structure of human memory. Cognitive Neuropsychology, 5(2), 193-211. doi:http://doi. org/10.1080/02643298808252933

Turner, A. D., Furey, M. L., Drevets, W. C., Zarate, C., \& Nugent, A. C. (2012). Association between subcortical volumes and verbal memory in unmedicated depressed patients and healthy controls. Neuropsychologia, 50(9), 2348-2355. doi:http://doi.org/10.1016/j.neuropsychologia.2012.06.003

Wechsler, D. (1987). Weschler Memory Scale revised manual. New York: Psychological Corporation.

World Health Organization. (2012). Good health adds life to years: Global brief for World Health Day. Geneva: Author. 